\title{
HVAD ER KULTURFORSTÅELSE?
}

Videnskabsteoretiske overvejelser omkring studiet af fremmede kulturer

\author{
Lars Albinus
}

ENGLISH ABSTRACT: This essay reflects on the conditions for approaching the study of cultures other than one's own. Departing from a quotation by Wittgenstein, I acknowledge the basic suggestion that no understanding takes place unless speech and acts are realised through common rules. Referring to Putnam, I further suggest that the thesis of incommensurability is unattainable inasmuch as some level of similarity (and the possibility of translation) is a condition of possibility for recognising differences. I also claim that notions of objectivity, explanation and representation are not apt to fit the prospect of the study of human realities. This does not entail the view that a humanistic approach will end up being relativistic. The source material always sets limit to reasonable interpretations and interpretations will always have to meet the demand of justification. Still, the entirely hermeneutic approach which only deals with the premises for understanding on the level of dialogue is important but insufficient in itself as a scientific approach. Referring to Foucault I therefore point to the twin birth of 'meaning' and 'system' in the history of human sciences, thus allowing an analysis of structures, cultural codes, social functions, cognitive dispositions to contribute to the scope of critical interpretations in so far as such studies recognise themselves - not as analogical to explanations in the natural sciences - but exactly as ways of interpretation.

DANSK RESUME: Artiklen reflekterer over muligheden for en videnskabelig forståelse af fremmede kulturer. Med udgangspunkt i et citat af Wittgenstein hovder jeg, at en forudscetning for overhovedet at forstå tale og handling er, at vi på et vist niveau deler regler, der gør dem mulige. Med Putnam insisterer jeg endvidere på, at kulturer må vare relativt sammenlignelige, hvis vi overhovedet skal kunne kende forskel på dem. Krav om objektivitet, forklaring og reprcesentation kan ikke legitimt stilles til en humanvidenskabelig diskurs, men det betyder ikke, at denne behøver at ende i relativisme. Kildematerialet vil altid begrcense fortolkningsmulighederne, og enhver fortolkning bør altid tilfredsstille et krav om begrundelse. En hermeneutisk tilgang til tekster inden for dialogens horisont betragter jeg som vigtig, men i sig selv utilstrcekkelig, for en videnskabelig diskurs, og i forlcengelse af Foucault henviser jeg til det videnskabshistoriske foellesskab mellem 'betydning' og 'system', der således bygger bro mellem på den ene side forståelsen og på den anden side analysen af strukturer, koder, funktioner og kognitive dispositioner. Disse niveauer er uomgangelige for en kritisk forståelse, der imidlertid ikke må forstå sig selv i analogi til naturvidenskabens forklaringspratention, men netop som fortolkning. 
KEYWORDS: Science, Culture, Comparability, Understanding

\section{Indledning}

“Tænk dig, at du som forsker kom til et ukendt land med et for dig helt fremmed sprog. Under hvilke omstændigheder ville du sige, at disse mennesker giver befalinger, forstår dem, efterkommer dem, handler i modstrid med dem o.s.v.?” Dette spørgsmål stiller Wittgenstein i Filosofiske Undersøgelser (1971, § 206) og kommer selv med et foreløbigt, om end noget nødtørftigt, svar: "Den fællesmenneskelige handlemåde er det referencesystem, ved hjælp af hvilket vi tyder et fremmed sprog". Svaret afføder vel blot et nyt spørgsmål om, hvorledes dette skal forstås. Umiddelbart kunne det udlægges sådan, at Wittgenstein vil hævde, at de sproglige symboler slet og ret afspejler en bestemt handlemåde. Som vi handler, således taler vi, og omvendt har vi med vores langvarige tilvænning til talen indkodet et register af mulige handlinger. I en vis overfladisk forstand er dette forkert. Vi kan sagtens foretage os noget, der er i modstrid med, hvad vi siger, men på et dybere niveau er det måske rigtigt nok, nemlig, at vi for at forstå hvad noget betyder, må være i stand til at forestille os - eller i det mindste reagere på - den situation, og de til situationen hørende handlinger, som ytringen refererer til. Wittgenstein fortsætter sit eksempel:

\footnotetext{
Lad os tænke os, at menneskene i dette land udfører almindelige menneskelige aktiviteter, hvorved de tilsyneladende betjener sig af et artikuleret sprog. Betragter man deres adfærd, så er den forståelig, synes os 'logisk’. Men prøver vi at lære deres sprog, opdager vi, at det er umuligt. Hos dem er der nemlig ingen regelmæssig sammenhæng mellem det talte, lydene og handlingerne; og dog er disse lyde ikke overflødige; thi knebler vi f.eks. et af disse mennesker, så får det de samme følger, som hos os: uden lydene går der forvirring i deres handlinger - som jeg vil udtrykke det. Skal vi sige, at disse mennesker har et sprog: befalinger, meddelelser, o.s.v.? For at være det, vi kalder 'sprog', mangler regelmæssigheden $(\S 207)$.
}

Det er omdiskuteret, hvorledes dette tankeeksperiment egentlig skal forstås, og den diskussion skal ikke tages op her, men man kan i det mindste sige så meget, at Wittgenstein med sit konstruerede eksempel forsøger at anskueliggøre den nødvendige sammenhæng mellem det at kunne tale et sprog og det at kunne følge en regel. Endvidere går en af Wittgensteins hovedargumentationer i Filosofiske Undersøgelser på, at en regel kun kan tænkes som noget socialt. Det giver ingen mening at følge en regel i ensomhed, eller rettere: der skal to eller flere til for, at en adfærd overhovedet kan være en reguleret eller regelstyret handlen. For sprogopfattelsen betyder dette, at sproget $\mathrm{i}$ grundlæggende forstand er et socialt fænomen. Når sproglige udsagn refererer, så foregår referencen inden for et univers af regler og - som Wittgenstein tilføjer - af sprogspil, uden hvilke det sagte ikke ville give nogen som helst mening. Dette er en radikal sprogopfattelse, men radikaliteten består alene $i$, at en kausal relation mellem forestilling og sprog skæres over, ikke at sproglige udsagn kan betyde hvad som helst. Dette vil 
jeg vende tilbage til, men lad mig indtil videre begynde forfra med et andet spørgsmål.

\section{Kultur som humanvidenskabeligt genstandsområde}

Hvilken rolle spiller videnskaben i forsøget på at forstå fremmede kulturer? Den videnskabelige tilgang er selvsagt ikke den eneste mulige måde at begribe kulturforskelle på. Litterær fiktion, rejsebeskrivelser, personlige oplevelser vil på forskellig måde kunne bidrage til forståelsen af en kultur, der adskiller sig fra den, man selv kommer fra. Her er det vigtigt at være opmærksom på netop dette forhold i kulturforståelsen, at man med en - om man så må sige - førteoretisk og fordomsbetinget baggrund i ens egen kultur, forsøger at forstå noget umiddelbart fremmedartet. Kulturforståelse er ikke bare kulturforståelse. At vende et analytisk blik på den kultur, man selv er en del af, implicerer nogle andre forudsætninger end forsøget på at forstå en kultur, man ikke selv er en del af. Om ikke andet anskueliggør Wittgensteins eksempel også dette. Ikke desto mindre må en forståelse af det fremmede samtidig implicere noget, der er fælles. Ellers vil det ikke være muligt at hævde nogen form for forståelse overhovedet. Konsekvensen af en rendyrket kulturrelativisme må være, at der ikke gives noget kriterium for, om forståelse finder sted eller ej. Hvis forståelse derimod, ligesom sprog, er ensbetydende med at følge visse regler, er Wittgensteins pointe måske også den, at uden et sammenfald $\mathrm{i}$ regelmæssighed, kan der ikke foreligge nogen forstålse, men alene en projektion af ens medbragte forestillinger.

Opfattelsen af, at kulturer er så forskellige, at enhver beskrivelse eller forståelse af dem er en konstruktion uden naturlig forbindelse til kulturen selv, kaldes undertiden for inkommensurabilitetstesen. Hvis kulturer er usammenlignelige, kan vi naturligvis aldrig vide, om vi har forstået dem eller ej. Men min pointe her er egentlig en anden, nemlig den, at en antagelse af kulturers usammenlignelighed er performativt selvmodsigende. Derved forstås, at hvis det virkelig var sandt, så ville vi ikke være i stand til at hævde det. Filosoffen Hilary Putnam har således tilbagevist inkommensurabilitetstesen ved at pege på, at en forudsætning for at hævde kulturers forskellighed, er, at man taler ud fra en sammenlignelighed, der gør det muligt at kende forskel (1981, 113-19). Kulturer kan altså ikke være radikalt forskellige, men åbner altid som kulturer for oversættelsens mulighed. Det er en hermeneutisk grundpointe, at vi slet ikke kan lade være med at forudsætte forståelighed og oversættelighed, når vi læser en tekst. Om vi misforstår den eller ej, har intet at sige i den forbindelse. Forhåndsantagelsen er, at teksten vil kunne forstås, hvis vi blot kender betydningen af de tegn, den benytter sig af.

Hermed rejser der sig en katalog af spørgsmål, som netop stiller sig til teksten som tekst. Hvad består en tekst af? Man kan forsøge at forstå den som et direkte udsagn, hvor man forestiller sig at være en af dens intenderede læsere, eller man kan i det mindste læse den, som om den kunne have betydning for én, uanset om man tilhører dens intenderede modtagerkreds ej. I begge tilfælde kan man sige, at der er tale om en hermeneutisk tilgang til teksten. En tilgang, der med andre ord baserer sig på en forståelse af, hvad teksten siger, hvad den, om man så må sige, har på hjerte. For den tyske filosof Hans Georg Gadamer har en sådan forstående tilgang til teksten i virkeligheden meget 
lidt med videnskab at gøre. Der gives ikke en metode til forståelse, men alene en historisk betinget relation mellem tekst og læser, som ophæver det normal-videnskabelige forhold mellem erkendelsens subjekt og objekt (2003, 9-14). En sådan forståelsesproces kan sagtens tilsidesættes rent metodisk til fordel for andre opklarende indfaldsvinkler, men pointen er, at et sådant alternativ aldrig med rette vil kunne påkalde sig en forståelse, der vil kunne erstatte det hermeneutiske forhold til teksten. En tekst kan analyseres på mange måder, men forstås kan den kun på en måde, nemlig ved, at man i forventning om noget sandt forholder sig til det, teksten siger.

For en videnskabelig eller metodisk teksttilgang er denne sandhedsorienterede forståelse ikke blot utilstrækkelig, men ligefrem problematisk for et forsøg på at analysere, dvs. dissekere, de tekstlige konstituenter. I det omfang teksten ikke blot trækker en større meningshorisont med sig, men også et netværk af koder og strukturer, som forbinder den med andre tekster, og måske også forskellige former for praksis, ritualer eller lignende, indlejrer den sig i en sammenhæng, som transcenderer den rene meningsforståelse. Fortolkningstraditioners dialektiske interaktion er ikke i sig selv nok til at definere sammenhænge, som udgøres af et symbolsystem, et sociologisk funktionsrum eller et netværk af kognitive dispositioner. For at kunne analysere symbolsystemer, sociologiske funktionsrum eller kognitive dispositioner, må vi træde ud af den rene dialogs tryllekreds. ${ }^{1}$ I den forbindelse foretager videnskaben ganske vist det kunstgreb, at den lader, som om den udefra ser ind på en sammenhængende orden, der er uafhængig af videnskaben selv. Dette $e r$ et kunstgreb, for så vidt som det på den ene side er udtryk for en illusion og på den anden side en nødvendighed i forsøget på at grave sig ned under den blotte forståelses udsatte og manipulerbare position. Således må man lykønske den form for empirisk arbejdende videnskab, som formår refleksivt at forholde sig til den fremskaffede videns status som fortolkning og drage den nødvendige konsekvens heraf. Konsekvensen er ikke nødvendigvis relativisme, men en indrømmelse af, at den videnskabelige analyses genstand ikke var et uafhængigt objekt, men allerede på forhånd del af den bagvedliggende videnskabs selvforståelse.

Inden jeg fortaber mig i ørkesløse refleksioner over, hvorvidt humanistisk viden $\mathrm{i}$ analogi med naturvidenskabelig viden dermed er mulig eller ej, vil jeg forsøge at bevæge mig ind på spørgsmålet om repræsentation. Hvad repræsenterer den videnskabelige tilgang til fremmede kulturer egentlig?

\section{Repræsentation ${ }^{*}$}

Hvis forståelse er en aha-oplevelse, der kræver en særlig form for indlevelse eller genkendelse, må den videnskabelige tilgang til fremmede kulturer give afkald på forståelse,

${ }^{1}$ At det i en vis forstand er dialogen, der overhovedet 'åbner' det fremmede og gør det til genstand for forståelse, ændrer ikke på, at dialogen samtidig kan forhindre den analyserende distance, som i praksis er nødvendig for at forstå det, der som dialogens konkrete forudsætning ikke kan tematiseres i dialogen selv.

${ }^{*}$ Begrebet om repræsentation drejer sig i denne forbindelse alene om den videnskabelige repræsentation af forskningsgenstanden, ikke om repræsentation i mentalistisk eller sociologisk betydning, som f.eks. Durkheims begreb om 'kollektive repræsentationer'. 
eller sagt på en anden måde: en sådan form for forståelse vil aldrig kunne definere en videnskabelig kulturopfattelse. Hvis der finder nogen form for genkendelse sted, må det være som resultat af et omhyggeligt analytisk arbejde, der på en begrebslig og systematisk måde synliggør den sammenlignelighed, som i udgangspunktet gjorde undersøgelsen mulig uden nødvendigvis at have været synlig eller bevidst for nogen. Synliggørelsen af relationer, strukturer, regler eller koder, der fremstiller teksten i et nyt lys, må ikke uden videre forveksles med en forklaring af teksten. I den udstrækning forklaring har med kausale, dvs. nødvendige, relationer at gøre, findes der formentlig kun meget få forklaringer inden for humanvidenskaben. I en løsere forstand kan alle mulige analyser og redegørelser siges at være forklaringer, men i en mere snæver betydning er det vigtigt at kunne forsvare sig over for en reduktionisme-anklage ved klart at frasige sig en egentlig forklaringsprætention. Anklagen kan nemlig kun fremsættes med rette, hvis man eksplicit eller implicit har insisteret på en kausal sammenhæng i de relationer, analysen har bragt for en dag. Som eksempel kunne man forestille sig et udsagn fra en ikke-humanistisk disciplin, nemlig hjerneforskningen, om, at religiøse åbenbaringer (dvs. et genstandsområde for humanvidenskaben) kan forklares som en elektromagnetisk påvirkning af tindingelappen. Selv hvis en hypotetisk induktion måtte vise, at der i hvert eneste tilfælde af åbenbaringer var tale om en påvirkning af tindingelappen, ville man forveksle nødvendige omstændigheder med tilstrækkelige omstændigheder, hvis man betragtede udsagnet som en (tilstrækkelig) forklaring. Eksemplet er selvfølgelig firkantet og sætter tingene på spidsen, men pointen er, at det ikke kan være i humanvidenskabens interesse at låne et forklaringsbegreb fra naturvidenskaberne for evt. at komme fortolkningens vilkårlighed til livs.

Humanvidenskaben har et historisk problem med begrebet fortolkning. I nogle sammenhænge vil man endnu kunne se en association mellem fortolkning og indlevelse, som man i andre sammenhænge, og af gode grunde, forsøger at distancere sig fra. Lad det ikke være en strid om ord, selvom ord netop er vigtige, men lad os for at undgå misforståelser og begrebsforbistring betragte problemet omkring den videnskabelige tilgang til fremmede kulturer som et problem angående et spørgsmål om repræsentation.

\section{At kunne kende forskel}

Hvis vi for argumentets skyld betragter kildematerialet til den videnskabelige undersøgelse af en fremmed kultur som en tekst, så rejser et spørgsmål sig uundgåeligt, nemlig 'hvad står det videnskabelige arbejde med tekstens egentlig for, hvad repræsenterer det?' Man kunne i princippet hævde, at det resultat, analysen fremlægger, netop må repræsentere tingen i sig selv, uanset om det drejer sig om koder, funktioner, mytemer eller meningsindhold, for så vidt som analysen skal kunne påberåbe sig objektiv gyldighed. Men spørgsmålet er, om objektivitet overhovedet er et relevant kriterium i den forbindelse, om ikke netop objektivitetskriteriet trækker et ligeledes uvedkommende begreb om kausalitet med sig? Nogle vil hævde, at relativisterne inden for humanvidenskabens rækker er en samling skuffede positivister, som i erkendelse af, at objektiv og værdifri viden ikke er mulig inden for humanvidenskaben, indstiller sig på, at alle teori- 
er og fremstillinger kan være lige gode. Dette ville være ensbetydende med at opgive enhver prætention om videnskab. Hvis relativisme i videnskabsteoretisk forstand forstås som opfattelsen af, at et hvilket som helst videnskabeligt udsagn fremsættes inden for et lokalt eller tilfældigt perspektiv uden universel gyldighed, må det implicerede videnskabsbegreb opløse sig selv og give afkald på enhver form for erkendelse (inklusive erkendelsen af altings relativitet naturligvis). Det er naturligvis ikke det samme som den grundindstilling, der består i beredvilligheden til at sætte noget, lige gyldigt hvad, i relation til andet. Blot må man samtidig give agt på den risiko, der består i, at alt i princippet kan relateres til alt muligt andet, afhængigt af synsvinklen, hvormed man ikke længere kan kende forskel på noget som helst. En sådan form for praktisk eller metodisk relativisme, der ikke nødvendigvis svarer til en erkendelsesteoretisk relativisme, demonstrerer blot en mangel på kritisk sans, der gør den uinteressant, men principielt er der intet ulovligt, eller selvmodsigende i den.

Det, som spørgsmålet om repræsentation bør lade sig afløse af, for så vidt som objektivitet eller korrelation mellem det videnskabelige begreb og dets genstand ikke udgør et brugbart kriterium, må være et spørgsmål om at kunne kende forskel. Umiddelbart kunne det måske ligne et paradoks, at forudsætningen for at kunne kende forskel består i et fælles grundlag. Det er imidlertid tvingende nødvendigt for forskellen, at den viser sig på baggrund af sammenlignelighed.

Derfor kan fremmede kulturer heller ikke beskrives neutralt, fordomsfrit og rent empirisk. Forudsætningen for at en beskrivelse og en analyse med henblik på forskellige sammenhænge, strukturer, funktioner, osv. overhovedet kan finde sted er, at noget allerede forstås som noget; at der finder en oversættelse sted, som skaber den orden i genstandsområdet, der gør det tilgængeligt for beskrivelse. Her er det, som Gadamer og andre har påpeget, en illusion, at man skulle kunne tilsidesætte sine fordomme. Fordomme er ikke noget, der blokerer for forståelsen af det, man betragter, men tværtimod noget, der muliggør en betragtning (2003, 259-271). Af samme grund er objektivitet ikke en relevant målsætning i humanvidenskabelig sammenhæng. Jeg har allerede advaret mod den relativisme, denne opfattelse kunne synes at invitere til. Men relativismen er, i mine øjne, en misforstået reaktion på objektivitetens humanvidenskabelige umulighed. Igen må vi skelne i mellem to niveauer af en humanvidenskabelig kulturforståelse. I modsætning til Gadamer vil jeg hævde, at tekstfortolkning kan og bør være en del af den videnskabelige praksis, men at den sjældent kan stå alene. I stedet for at insistere på en kløft mellem en hermeneutisk tekstopfattelse og en analytisk tekstopfattelse vil jeg i lighed med Foucault henvise til deres fælles ophav i en interesse for teksten som medium for en forståelse af mennesket $(2002,412-416) .{ }^{2}$ I forholdet mellem hermeneutik og tekstanalyse indgår et forhold mellem 'betydning' og 'system', som er konstituerende for tilblivelsen af den humanvidenskabelige tekstforståelse. Hermeneutikken trækker mod betydningsbegrebet, strukturalismen trækker imod systembegrebet, hermeneutikken er ideografisk orienteret, strukturalismen er mere nomotetisk orienteret, hermeneu-

\footnotetext{
${ }^{2}$ I hermeneutikken er det ganske vist sagen selv, der er forståelsens genstand, men det er stadig som et menneskeligt anliggende, at sagen overhovedet åbner sig for forståelse.
} 
tikken insisterer på en pragmatisk sprogforståelse, strukturalismen insisterer på en empirisk sprogforståelse, men dybest set udspringer begge positioner af en interesse $i$ at forstå menneskelige udsagn $\mathrm{i}$ den traditionskontekst, som virker gennem dem. Og i begge tilfælde er der tale om en delagtighed i genstandsfeltet, som placerer det uden for et snævert objektivitetskriterium.

Jeg har indtil videre argumenteret for, at kulturforståelse ikke handler om objektiv repræsentation, men derimod om at kende forskel. Det svarer imidlertid ikke umiddelbart på spørgsmålet om, hvad det rent faktisk er, man siger noget om. Hvis sådanne forskelle, som f.eks. forskellige opfattelser af forholdet mellem kønnene, af menneskets skæbne efter døden eller andet, ikke udtrykker omstændigheder ved en ydre realitet, hvad da?

\section{Bevidstheden, sproget og den sociale væren}

Som kultur- og religionsforsker kan man næppe undgå at stille sig selv et grundlæggende spørgsmål om, hvad det er, der skaber 'betydning', ja, hvad betydning i det hele er for noget. Det er nemlig ikke så enkelt endda. Hvis man som pragmatiker hævder, at betydning bliver til ved, at noget betyder et eller andet for nogen, forskyder det blot spørgsmålet til, hvad dette så betyder, ligesom anvendelsen af ordet 'betydning' i denne og ovenstående sætning ikke nødvendigvis implicerer, at 'betydning' betyder noget for nogen bestemt. Selvfølgelig er det en dimension ved ordet 'betydning', at betydning opstår i kommunikation, men vi anvender ofte ordet, med rette eller urette, om noget, som ingen nødvendigvis er bevidste om. Man kan gennem sammenligninger af forskellig art finde betydninger i ritualer, som ingen af de deltagende nødvendigvis forbinder noget med. Betyder det, at den påviste betydning så ikke er til stede, eller, at vi har misbrugt selve ordet 'betydning'?

Dette er et meget stort diskussionsfelt, som jeg på ingen måde kan yde retfærdighed ved de få kommentarer, der er plads til her, men jeg vil blot pege en enkelt omstændighed ved det spørgsmål omkring begrebet betydning, som rejser sig, når det gælder beskrivelsen af en fremmed kultur. Dette fører os tilbage til begrebet 'repræsentation' eller rettere til opgøret med dette begrebs anvendelighed i objektivistisk forstand.

Der er således to indbyrdes forbundne grunde til, at en sådan forestilling om repræsentation fører os på afveje. På den ene side den meget enkle grund, at andres bevidsthed ikke er tilgængelig for os, på den anden side den grund, som det nok er sværere at begribe fuldt ud, nemlig, at det vi siger og gør er så dybt forbundet med sociale og kulturelle forudsætninger, at der i en vis forstand ikke er tale om noget privat eller 'indre', men om noget, der allerede i udgangspunktet er et produkt af, hvad man kunne kalde en kulturel grammatik.

Hvis vi først forholder os til spørgsmålet om bevidsthed, må man selvfølgelig tage det umiddelbare forbehold at skelne mellem kulturer, og det vil her for nemheds skyld sige tekster, der hører en udlevet fortid til, og tekster, fortidige eller nutidige, der indgår i en levende kultur. For de sidstes vedkommende er graden af tilgængelighed naturligvis meget større, og man kan gennem feltstudier indarbejde forskellige menneskers selvop- 
fattelse i den videnskabelige analyse. Pointen er imidlertid, at denne forskel mellem kilder fra en død og fra en levende kultur kun er en relativ forskel, der ikke ændrer det fælles vilkår, at alle kulturelle manifestationer eksisterer i et rum af tegn.

Dette fører os over til det andet punkt, nemlig at sprog ikke, som bl.a. Wittgenstein har søgt at vise (1971), udtrykker et tankeindhold, der som sådan går forud for sproget, men at sproget omvendt går forud for bevidstheden i den forstand, at det åbner den sociale verden for os, som vores bevidsthed bliver til i. Pointen er ikke at afvise, at den enkelte kan føle sig uden for eller have religiøse oplevelser, som går på tværs af de gældende normer. Den sociale væren, der her er tale om, ligger dybere. Den er, om man så må sige, det sammenligningsgrundlag, der gør forskelle mulige. Når man i videnskabens tjeneste forholder sig til andre kulturer, gør et lignende forhold sig gældende. Vi er ikke en del af den fremmede kulturs sociale væren, vi står uden for den pågældende kulturs indsocialiserede forståelsesniveau, om man så må sige. Men i modsætning til Winchs opfattelse (1977) betyder dette vilkår i mine øjne ikke, vi bliver nødt til at afklæde os vores egne kulturelle forudsætninger for - så vidt muligt - at iklæde os nogle andre. Et sådant 'going native' ideal udtrykker for mig at se blot en variant af oplysningstidens illusion om fordomsfrihed. Når vi møder andre kulturer, om det så blot er gennem tekster, har vi naturligvis vores egne kulturelle forudsætninger med; men med selve oversættelsens mulighed, som til gengæld er en betingelse, indtræder vi i en sproglig og dermed meta-kulturel væren, på hvilken vi har adgang til teksters betydning. Tekster betyder altså altid det, de betyder for os; men dermed ikke sagt, at vi er bundet til en hermeneutisk, endsige vilkårlig, forståelsesproces, som er fritaget for videnskabelig metode.

Grundpointen er, at kriteriet for betydning aldrig er den enkeltes bevidsthed som sådan, men den enkeltes mulighed for at tale og handle i overensstemmelse med det, som socialiteten på et dybtliggende, og derfor ubevidst niveau, manifesterer i sig selv. At spørge en person, hvad han eller hun forestiller sig ved en given rituel handling, eller hvordan han eller hun forstår pointen $i$ en given myte, fortæller os i virkeligheden meget lidt om den rituelle handlings eller om mytens betydning. Betydning hører til på et niveau, der kan bevidstgøres, men som ikke nødvendigvis er det i sig selv. Af samme grund hører strukturelle relationer, koder og funktioner også til på et betydningsniveau, selvom det ikke nødvendigvis afspejles i deltagernes egen bevidsthed. Den betydning, der knytter sig til det, som en videnskabelig metode fremanalyserer som mulighedsbetingelser, strukturer, koder og funktioner, er klart nok først og fremmest betydninger for os, dvs. for vores forståelse af den pågældende kultur. Det betyder ikke, at disse begreber er udtryk for en fiktiv projektion, men de er heller ikke objektive fænomener i lighed med kausale relationer. De er først og fremmest et udtryk for, hvorledes en kultur inden for rammerne af en interkulturel og i snævrere forstand intersubjektiv horisont lader sig forstå. Vi placerer os et sted mellem naturvidenskabelig objektivitet (som imidlertid heller ikke er nær så entydig, som mange forestiller sig) og fiktiv konstruktion, men sådan er vilkåret. Når det ikke medfører, at vi kan gøre hvad som helst gældende, så skyldes det naturligvis det foreliggende referencegrundlag. Kildeuniverset sætter 
grænser for, hvad en fortolkning kan bære. Respekten over for kilderne, deres historiske rekonstruktion, thick description, osv., er det, der garanterer videnskabeligheden af vores analyser.

\section{Diskursanalyse, intertekstualitet}

Til slut vil jeg kort komme ind på begreber om diskursivitet og intertekstualitet. I det øjeblik, man har opgivet forestillingen om, at det er forestillinger eller materielle referencer, der definerer religiøse eller i det hele taget kulturelle teksters betydning, rejser der sig et spørgsmål til, hvad der overhovedet organiserer tekster i forhold til hinanden og i forhold til den virkelighed, de trods alt er - eller foregiver at være - udsagn om. Her er det naturligvis ikke nok - eller det er rettere sagt tautologisk - blot at angive kulturen eller socialiteten som svar.

Til gengæld mener jeg heller ikke, at henvisningen til en kulturs 'verdensbillede' er et tilfredsstillende alternativ. I virkeligheden kunne forestillingen om et verdensbillede godt ligne en ekstrapolation eller projektion af den traditionelle bevidstheds- og individorienterede tekstopfattelse. I stedet for at tale om et forhold mellem sprog og sprogbruger taler man om individer, der forholder sig, positivt eller negativt, til den kultur, de selv er en del af, og ligesom en tekst fortolkes med henblik på tankens og meningens enhed, fortolkes kultur med henblik på den folkelige mentalitets, eller verdensbilledets, enhed. Det er en sådan opfattelse af sprog og kultur, jeg har forsøgt at gøre op med.

Sprog og kultur er ikke meningsenheder, men betydningsmuligheder, ikke en homogen, men en heterogen erfaringsvirkelighed. Nok kan vi tale i overordnede termer om kulturforskelle, som om der var tale om forskellige verdensbilleder, men netop oversætteligheden de forskellige kulturer imellem gør måske spørgsmålet om verdensbilleder til noget sekundært. Vi forholder os i forskellige kulturer meget forskelligt til den virkelighed, vi alle sammen lever i, ja, vi kunne gå så langt som til at sige, at vi lever i forskellige virkeligheder, der alene forbindes af de broer, som oversættelighed anbringer mellem dem, men det er langt fra sikkert, at vi gør os selv en tjeneste ved at tale monolitisk om forskellige verdensbilleder.

Risikoen er på den ene side, at man overser de fællestræk af forskellig art (strukturelle, kognitive osv.), der kunne tænkes at være mellem forskellige kulturer, og på den anden side, at man mister blikket for den heterogenitet, der hersker i hver enkelt kultur.

Det er her, begreber som 'diskurs' og 'intertekstualitet' har deres berettigelse. Når man skifter fokus fra en forståelse af tekster som medier for bevidsthedsindhold eller ydre referencepunkter til en forståelse af den sammenhæng, tekster indgår i som tekster, åbner man i højere grad øjnene for, hvorledes de betinger hinanden. De gensidigt konstituerende relationer, hvormed tekster udgør en mere eller mindre lukket enhed, kan kaldes for en diskurs. Diskursen er - materielt set - resultatet af de regler, der er gældende for, hvilke udsagn der gyldigt eller meningsfuldt kan fremsættes i en given sammenhæng om et givet genstandsområde. Det er i særdeleshed Michel Foucault, der i relation til humanvidenskaben og andre vidensområder med omfattende historiske studier har anvist, hvorledes rekonstruktionen af umiddelbart fremmedartede menings- 
sammenhænge kan udføres, og det skal ikke nærmere omtales her. Det, det drejer sig om for diskursanalysen, er at undersøge tekster i de indbyrdes relationer, hvormed de tilsyneladende (for beviser gives der aldrig) danner en formation. Endelig forholder de enkelte formationer sig ligeledes, og ofte polemisk til hinanden, hvorfor man, i stedet for at rekonstruere en given kulturs verdensbillede, bør stille skarpt på betydningen af forskellige diskursive interaktioner. Diskursanalysen kan f.eks. være med til at bløde op på stereotyper som f.eks. en forskelstænkning mellem hedenske og kristne traditioner i oldtiden, eller mellem orientalske og occidentale traditioner, netop ved at foretage en analyse af intertekstuelle relationer inden for de enkelte diskurser i lyset af interdiskursive spændinger, der ofte skærer tværs gennem de enkelte diskurser, ja endda de enkelte tekster. Diskursanalysen er anlagt på at synliggøre det netværk af forskellige relationer, der konstituerer den enkelte tekst lige fra den enkelte sætning til det overordnede 'clash of civilizations'. Jeg har ikke med denne alt for kortfattede antydning af diskursanalysens bidrag til kulturforskningen ønsket at plædere krypto-objektivistisk for en ny og bedre videnskabelighed. En af diskursanalysens fordele er, at den undgår det niveau af bevidsthedsmæssig referentialitet, som i mine øjne ikke kan være et kriterium i kulturforskningen, fordi det trækker på en uhensigtsmæssig og i øvrigt forældet dualistisk subjekt-objekt tænkning, men dermed hævder diskursanalysen heller ikke, at den fremstiller det sande objekt. Den skaber blot et blik for nogle relationer, som ellers kunne have undgået vores opmærksomhed, men som faktisk gør os i stand til at skabe en kritisk distance til den selvopfattelse, hvormed forskellige kulturelle udsagn beskytter sig selv. Det er netop denne distance, som den rent hermeneutiske tilgang ikke i samme grad kan garantere. Tekst- og kulturforståelse drejer sig således ikke blot om at forstå, hvad tekster siger ud fra sig selv som udsagn, der henvender sig til en læser (igen kun et lille og kunstigt udsnit af det religionsvidenskabelige kildemateriale), men også om de forhold, der gør sig gældende forud for den enkelte tekst eller, om man så må sige, neden under dens eksplicitte 'intention'. Strukturelle og diskursive analyser har begge til formål at trænge ned under tekstens eget udsigelsesniveau til den underskov af forudsætninger, som overhovedet gør dens betydningsdannelser mulige. Det betyder ikke, at strukturelle og diskursive analyser er fritaget for et fortolkningsniveau. De er i bund og grund fortolkende. Den formalisme, som mange analytikere synes at besmykke sig med, er blot et slør for, at der selvfølgelig er tale om en fortolkning, der på forhånd involverer den fortolkende og det fortolkede med hinanden i en fælles metakulturel væren. Imidlertid tror jeg, at man netop som udefrakommende, dvs. som participant i en anden kultur, har større chancer for at fremanalysere en kulturel grammatik, der ikke blot gentager en kulturel selvforståelse i nye klæder. I den forstand kan kulturanalyse både bidrage til at kaste et nyt lys over den kultur, man undersøger, og den kultur, man selv kommer fra.

Endelig en afsluttende kommentar om det princip, jeg har gjort gældende som et princip om at kunne kende forskel. Jeg har jo netop argumenteret for, at diskursanalysen kan være med til at nedbryde nogle af de stereotype mærkater, der traditionelt har været hæftet på forskellen mellem øst og vest, mellem sorte og hvide, mellem hedenskab og kristendom, osv. Alligevel mener jeg ikke, at jeg har gjort mig skyld i en principiel 
selvmodsigelse. Det er netop den strukturelle og den diskursive analyses fortjeneste at skabe et grundlag for at nedbryde forskelle på dette niveau. Risikoen er imidlertid, at man ender med at nivellere alting til mere eller mindre ensartede strukturer i l'esprit humaine (jf. Lévi-Strauss) eller mere eller mindre universelle strategier i diskursiv interaktion som sådan. Hvis dette bliver resultatet mister det strukturalistiske og diskursanalytiske arbejde sin kritiske værdi. Mellem de store ideologisk betingede forskelle og det alment udstrakte netværk af strukturer og magtrelationer består de kulturer og de kulturelle forskelle, som ikke mindst er interessante i forhold til en agtpågivende selvopfattelse, der også i relation til vores egen videnskabelige og kulturelle sammenhæng er eller bør være åben for kritik.

Alt er ikke ens, men intet er os heller fuldkommen fremmed.

Lad mig til slut samle op på det foregående gennem en opstilling af nogle af de væsentligste begreber:

\section{UFRUGTBARE BEGREBER \\ - Forestillinger (indlevelse) \\ - Repræsentation \\ - Objektivitet \\ - Forklaring \\ - Mentalitet \\ - Verdensbillede \\ - Inkommensurabilitet}

\author{
FRUGTBARE BEGREBER \\ - Tegn/Tekster (tekstlig betydning) \\ - Diskursivitet \\ - Intersubjektivitet \\ - Fortolkning \\ - Kulturel grammatik \\ - Diskursiv interaktion (intertekstualitet) \\ - Sammenlignelighed
}

Vigtige bestræbelser i en humanvidenskabelig kulturforståelse:

a) At forstå tekster, ikke bevidstheder

b) At nedbryde stereotyper

c) At kunne kende forskel

d) At undgå relativisme

e) At indse intersubjektive erkendelsesbetingelser og

f) Forpligte sig på et intersubjektivt gyldighedsniveau

g) At frasige sig et kausalt forklaringsbegreb

h) At vedkende sig et fortolkningsniveau

i) At synliggøre usynlige eller ubevidste konstituenter (strukturer, funktioner, koder, regler, kognitive dispositioner, o.lign.)

\section{Litteratur}

FOUCAULT, MicheL

2002 Ordene og tingene. En arkcoologisk undersøgelse af videnskaberne om mennesket, København, Gyldendal. 
GADAMER, HANS-GEORG

2003 Sandhed og metode (oversat af Arne Jørgensen), Systime, Århus.

PuTNAM, HiLARY

1981 Reason, Truth and History, Cambridge, Cambridge University Press

WINCH, PETER

1977 "Understanding a Primtive Society", i Bryan R. Wilson, ed., Rationality, Oxford, Basil Blackwell, 78-111.

WiTTGENSTEIN, LUDWIG

1971 Filosofiske Undersøgelser, Samlerens Bogklub [1958], København.

Lars Albinus

Lektor

Afdeling for Systematisk Teologi Afdeling for Religionsvidenskab

Aarhus Universitet 